\title{
Analysis of the Dimensions and Determinants of Household Food Security Status among Maize Farming Households in Lagos State, Nigeria
}

\author{
Joseph AHMADU*, Toyin D. AJAYI and Okiemua T. OKOROR \\ Department of Agricultural Economics and Extension Services, Faculty of Agriculture, University of Benin, \\ P.M.B. 1154, Benin City, Edo State, Nigeria
}

\begin{abstract}
The study focused on analysis of the dimensions and determinants of household food security status among maize farming households in Lagos State, Nigeria. The specific objectives of the study were to describe the socioeconomic characteristics of the respondents, examine the dimensions of food security status of the households, determine their food security status and examine the factors influencing food security among the maize farming households in the study area. Primary data for the study were obtained from 155 maize farming household heads with the aid of structured questionnaire. Descriptive statistics, food security index assessment and logit regression model were used to analyse the data. The results showed that majority (91.6\%) of the households were headed by males who were aged 59 years, on the average, married (91.6\%) and their level of literacy was very high as all of the respondents had a form of formal education. The mean household size of the study area was 7 members. The household heads had farming experience of 32 years, a mean farm size of 2.14 hectares for maize farming and an average of 1.24 hectares for farming other crops. The results further showed that $77.4 \%$ of the household heads perceived food to be moderately available for consumption throughout the year, $81.3 \%$ had three square meals each day and $81.2 \%$ perceived their food quality consumed to be high all year round. Consequently, majority $(97 \%)$ of them were food secure. Significant determinants of food security status among the households were farm size, household size and access to credit facilities. Farm size and access to credit facilities influenced food security positively while household size affected it negatively. It was recommended that government should create enabling environment for the farmers to have easy access to more arable land and credit facilities to help them expand their production in order to improve food security for both the farmers and the citizens at large.
\end{abstract}

Keywords: food security, household, socio-economics

DOI: $10.7176 / \mathrm{JESD} / 12-20-04$

Publication date:October $31^{\text {st }} 2021$

\section{Introduction}

The global population was estimated at 6.07 billion for 2000 and it is projected to grow to around 9 billion by 2050 (Millennium Institute, 2013). According to the report, this growth is said to profoundly impose challenges in meeting future food consumption. Despite the persistent decline in global hunger, about 795 million people are chronically hungry and cannot lead a healthy active life (FAO/IFAD/WFP, 2015). Food insecurity continues to be a major developmental problem across the globe, undermining people's health, productivity, and often their very survival.

FAO (2010) defines food insecurity as the "consequences of inadequate consumption of nutritious food". Food security is built on four main dimensions, viz, food availability, accessibility, utilization and stability (Jrad et al., 2010). Drawing from numerous authors, Ahmadu and Okoror (2019) discussed these dimensions in details. According to them, food availability is concerned with the physical supply of food which could be from own-farm production or purchase. It indicates whether the quantity of food supplied is sufficient. Food accessibility deals with the ability of an individual or household to acquire sufficient quality food for active and healthy living. It is a function of food distribution, individuals or households' income, food prices as well as social and political factors influencing the acquisition of the food. Food utilization refers to the safety of the food for ingestion to meet the physiological requirements of the individuals. The ability to have adequate food supply all year round is referred to as food stability. This is sustainability of access to food. When these four main dimensions of food security are not satisfied, food insecurity is said to exist.

Agriculture has contributed immensely by helping to maintain a healthy population; it has been a source of food and nutrition for households in Nigeria. However, it has not been very effective, especially from the time the country started the production of crude oil in commercial quantity in the mid 1960's till now (Alkali, 1997; Lawal, 1997; Adegbolaet al., 2011). Efforts to overcome the development challenges posed by food insecurity necessarily begin with accurate measurement of key indicators at the household level. This is due to the fact that identification of household behaviour relating to food access serves as a critical building block for the development of policies and programs for helping vulnerable populations, the effective targeting of assistance, and the evaluation of impact (Smith and Subandoro, 2007). 
Cereals have been known to be major foods in achieving food security of any nation (Onasanya and Obayelu, 2016). Maize is one of the world's most important cereals along with wheat and rice. Maize is currently produced on nearly 100 million hectares in 125 developing countries and is among the three most widely grown crops in 75 of those countries (FAOSTAT, 2010). It has been in the diet of Nigerians for centuries. It is one of the important grains in Nigeria, not only on the basis of the number of farmers that are engaged in its cultivation, but also on its economic value (Ogunlade et al., 2010; Olaniyi and Adewale, 2012). Rosegrant et al. (2008) estimated that by 2050 , the demand for maize in the developing world will double, and by 2025 , maize is likely to become the crop with the greatest production globally. These point to the significant role of maize production to sustainable development of rural economy, food security and poverty reduction especially in rural areas of Nigeria.

Several evidences have also suggested that majority of the world's food insecure live and work in the rural areas (IFAD, 2001). This indicates that reducing rural food insecurity is very important to reducing overall food insecurity. Moreover, an in-depth understanding of the dimension, socioeconomic and other factors influencing household food security deserve the undertaking of empirical studies. This would serve as a complementary indicator to assess the multiple dimensions and manifestation of food insecurity to initiate policies for more effective interventions and responses.

This study, therefore, analyzed the dimensions and determinants of household food security status among maize farming households in Lagos State, Nigeria. The specific objectives of the study were to describe the socioeconomic characteristics of the respondents, examine the dimensions of food security status of the households, determine their food security status and examine the factors influencing food security among the maize farming households in the study area.

\section{Methodology}

\subsection{Study Area}

Lagos State is located in the south western geopolitical zone of Nigeria, lying approximately between latitude $60.22^{\circ} \mathrm{N}$ and $60.2^{\circ} \mathrm{N}$ and longitude $20.42^{\circ} \mathrm{E}$ and $32.2^{\circ} \mathrm{E}$. It is bounded in the North and East by Ogun State of Nigeria, and in the West by Republic of Benin. Lagos State has a population estimated at 21 million in 2016, it covers an immense total area of 1,171.28 square kilometers (World Population Review, 2020). The State is divided into five administrative divisions of Ikeja, Badagry, Ikorodu, Lagos Island and Epe, which are further divided into 20 Local Government Areas (LGAs), 16 of the 20 LGAs comprise the statistical area of Metropolitan Lagos. The remaining four LGAs (Badagry, Ikorodu, Ibeju-Lekki and Epe) are within Lagos State but are not part of Metropolitan Lagos; they are areas with high agricultural production activities. Here, some of the major crops produced by the farmers are maize, cassava and vegetables.

\subsection{Sampling Procedure and Data Collection}

A list of maize farmers was obtained from Lagos State Agricultural Development Authority which served as a sampling frame for the study. A multi-stage sampling procedure was then employed to select the respondents for this study. The sampling process was carried out in three stages as follows:

Firstly, three LGAs (Epe, Ikorodu and Badagry) where there were farm settlements and large number of maize farmers were purposively selected out of the four LGAs in the State with high farming activities. Secondly, two towns with more maize farmers were purposively selected from each LGA to give six towns. These towns include: Ikorodu and Farm settlement in Ikorodu LGA, Agbowa and Epe in Epe LGA, and Badagry and Ikoga in Badagry LGA. Thirdly, a total of 155 respondents were randomly selected from the sampling frame of 173 using Krejcie and Morgan (1970) sample size formula at 95\% confidence interval.

The formula is expressed as:

$$
\text { Sample Size }=\frac{X^{2} N P(1-P)}{e^{2}(N-1)+X^{2} P(1-P)}
$$

Where:

Where: $\mathrm{N}=$ population size, $\mathrm{e}=$ acceptable sampling error $(0.05), \mathrm{P}=$ proportion of population (assumed to be $0.5)$, and $\mathrm{X}^{2}=$ table value of chi-square at degree of freedom 1 (3.841).

Primary data for the study were collected using structured questionnaire.

\subsection{Data Analysis}

The tools used for data analysis were descriptive statistics, Food Security Status analysis and logistic regression model. The descriptive statistics such as frequency distribution, mean, and percentages were used to analyze the socio-economic characteristics of the respondents and other average statistics. 


\subsubsection{Food security status analysis}

Food quantities consumed at the household level using the 30 days recall period were converted to calories using the available food consumption tables (Oguntona and Akinyele, 1995; Babatunde et al., 2007) and divided by 30 days to get the corresponding daily calories. The calorie values obtained were divided by the number of Adult Equivalent (AE) in the households in order to obtain numbers that are comparable across households of different size (Maxwell et al., 2000; Djangmah, 2016). A food secure household is defined as one whose calorie supply per $\mathrm{AE}$ is greater than or equal to the minimum daily calorie requirement for adult of $2730 \mathrm{kcal}$ based on FAO recommended food security line (FAO, 1996). Households with lower calorie intakes were considered to be food insecure. To compute the adult equivalent, OECD scale method (OECD 2011, OECD 2008) was used.

Food security index $(Z)$ is defined as:

$\mathrm{Z}=$ Household's daily per capita calorie availability

Household's daily per capita calorie requirement (I)

where, calories requirement $(I)=2730 \mathrm{kcal}$

Based on Z, two food security measures were calculated:

When $Z_{\mathrm{i}} \geq 1=$ Food secure ith household

$\mathrm{Z}_{\mathrm{i}}<1=$ Food insecure ith household.

\subsubsection{Logistic Regression Model}

Logistic regression was estimated to examine the determinants of food security among the respondents. The model was employed to identify potential explanatory variables affecting household food security status through the odd ratio (OR) estimates. The odd ratio represents the odds that an outcome will occur when given a particular exposure, compared to the odds of the outcome occurring in the absence of the exposure (Szumilas, 2010). The $\mathrm{z}$ value of the variable with positive sign indicates that the likelihood of a household to be food secure increases as the variable in question increases. Conversely, the $\mathrm{z}$ value that possesses negative sign indicates that such variable has an inverse relationship with the level of food security. That is, an increase in the variable in question, will lead to an increase in food insecurity among the households and vice versa.

The model Chi-square distribution in the logistic regression model indicates that farmer's socio-economic characteristics are relevant in explaining the dependent variable. This can be used to assess the significance of the model which presents the normal significant test for a logistic model, the likelihood ratio which tests the null hypothesis that none of the explanatory variables are linearly related to the log odds of the response variable. But it is an overall test which does not assure every explanatory variable is significant. The $p$-value of less than $1 \%$ probability level indicates that the null hypothesis is rejected. The log likelihood ratio indicates that the explanatory variables included in the model jointly explain the probability of household food security status.

The general function of logit model expressed by Bashir et al. (2012) is:

$\mathrm{Y}_{\mathrm{i}}=\beta_{0}+\beta_{\mathrm{i}} \mathrm{X}_{\mathrm{i}}+\mu$

Where:

$Y_{i}=$ Dependent or response variable of ith respondent ( 1 if household is food secure, 0 if household is food insecure) $\mathrm{B}$ is the estimated coefficient of the respective parameter, and ' $\mu$ ' is the error term. $Y i$ is a realization of a random variable that can take the values one and zero with probabilities $\mathrm{P}_{\mathrm{i}}$ and 1-P

The logit model can therefore be expressed as:

$\mathrm{P}_{\mathrm{i}}=$

$$
\frac{1}{1+\mathrm{e}^{-(\beta 0+\beta i X i)}}
$$

$1-\mathrm{P}_{\mathrm{i}}=$

$$
\frac{1}{1+\mathrm{e}^{\left(\beta 0+\beta_{i X i)}\right.}}
$$

The log odds of the probability that an individual is food secure is expressed as:

$\operatorname{Ln}(\mathrm{Pi} / 1-\mathrm{Pi})=\mathrm{Y}_{\mathrm{i}}=\beta_{0}+\beta_{\mathrm{i}} \mathrm{X}_{\mathrm{i}}$

When the response variable $Y_{i}=1$ then the probability of a household being food secure is $P_{i}$ and when it is $Y_{i}=0$, then the probability of a household being food insecure is $1-\mathrm{P}_{\mathrm{i}}$. The logarithmic transformation of equation (3) yields the Logit Regression Model. When the disturbance term $(\mu)$ is introduced, with $Y_{i}=$ a function of $k$ explanatory variables $(\mathrm{X})$, then the logit model is expressed as:

$Y_{i}=\beta_{0}+\beta_{1} X_{1}+\beta_{2} X_{2}+\beta_{2} X_{2}+\beta_{3} X_{3}+\beta_{4} X_{4}+\beta_{5} X_{5}+\beta_{6} X_{6}+\beta_{7} X_{7}+\beta_{8} X_{8}+\mu$

Where:

$\beta_{0}=$ Constant

$\beta_{1}-\beta_{8}=$ the regression coefficients which interpret the effect of $\mathrm{X}$ on $\mathrm{Y}$

$\mathrm{X}_{1}=$ Total income of the household per annum (naira)

$\mathrm{X}_{2}=$ Years of farming experience (years)

$\mathrm{X}_{3}=$ Total size of farm (hectares)

$\mathrm{X}_{4}=$ educational status of household head (years) 
$\mathrm{X}_{5}=$ age of household head (years)

$\mathrm{X}_{6}=$ household size (number of household members)

$\mathrm{X}_{7}=$ Access to extension services ( 1 for access; 0 for no access)

$\mathrm{X}_{8}=$ household head access to credit facilities ( 1 for access; 0 for no access)

$\mu=$ error term

\subsection{Results and Discussion}

\subsection{Socio -Economic Characteristics of Respondents}

The results of the socio-economic characteristics of maize farmers' households in the study area in Table 1 show that $91.6 \%$ of the households were headed by males while $8.4 \%$ were headed by females. This indicates that males owned and controlled farmlands more in the study area and maize producers were mainly male. The result agrees with Djangmah (2016) that farming households are predominantly male. The mean age of the household heads was 59 years, which compares favourably with USAID report (2005) which estimated the average age of farmers in Nigeria to be above 50 years.

Majority (91.6\%) of the maize farmers were married, $6.5 \%$ widowed, $1.3 \%$ separated, $0.6 \%$ divorced and none of the respondents were single. This implies that the maize farmers in the study area had responsibility to feed and care for their families, hence the need to increase production to achieve food security. The mean household size of the study area was 7 members. Only $0.6 \%$ of the households had above 13 members. The household size of 4 - 9 had a percentage of $70.3 \%$ as most of the maize farmers' households fell in this range. This result is in agreement with Ajah and Nmadu (2012) who reported that most household size of maize farmers in Abuja ranges between 4 - 9 persons with a total percentage of $70.63 \%$. This result is also in agreement with the report of Ehebhamen et al. (2017) that the rural farmers have a mean household size of 6 . Household size has great implication on the quantity and quality of food consumed and a strong indicator to food security, particularly where household members are mainly dependants.

It was observed that none of the respondents was an illiterate as all $(100 \%)$ of them had one form of formal education: Primary education (11\%), Secondary education (40\%), OND/Diploma (41.3\%), HND/BSc $(7.1 \%)$, Masters $(0.6 \%)$. Education is important as it helps to create positive mental attitude towards adoption of modern farming innovation. The high level of education in the study area is expected to have positive implication on the respondents' income and food security. On the average, the households in the study area had farming experience of 32 years, which indicates that the maize farmers were quite experienced and it is a desirable skill in farming which may impact positively on food production and in-turn affect food security.

The respondents had a mean farm size of 2.14 hectares for maize production and an average of 1.24 hectares for farming other crops, which indicate that maize is the dominant crop planted by the respondents. The small farm size might be due to the peculiarity of the study area being known as a mega city and have less land for agriculture compare to other states in the country.

The result also showed that $60 \%$ of the maize farmers' household heads belonged to social organizations and $72.3 \%$ belonged to cooperative society. About $60 \%$ of them had access to both extension services and credit facilities. This shows the level of participation of the government and the farmers to improve production and standard of living of farmers which might greatly reflect in their food security status as these factors directly affect food availability.

Table 1: Socio-economic characteristics of respondents

\begin{tabular}{|c|c|c|c|c|c|}
\hline Variable & $\begin{array}{l}\text { Frequency } \\
(n=155)\end{array}$ & $\begin{array}{l}\text { Percentage } \\
(\%=100)\end{array}$ & Mean & Minimum & Maximum \\
\hline \multicolumn{6}{|c|}{ Sex of household heads } \\
\hline Male & 142 & 91.6 & & & \\
\hline Female & 13 & 8.4 & & & \\
\hline \multicolumn{6}{|c|}{ Age of household heads (years) } \\
\hline$<40$ & 7 & 4.5 & & & \\
\hline $40-49$ & 12 & 7.8 & 59 & 34 & 76 \\
\hline $50-59$ & 46 & 29.6 & & & \\
\hline $60-69$ & 79 & 51 & & & \\
\hline$\geq 70$ & 11 & 7.1 & & & \\
\hline \multicolumn{6}{|c|}{ Marital status of household heads } \\
\hline Single & 0 & 0 & & & \\
\hline Married & 142 & 91.6 & & & \\
\hline Widow & 10 & 6.5 & & & \\
\hline Separated & 2 & 1.3 & & & \\
\hline Divorce & 1 & 0.6 & & & \\
\hline
\end{tabular}




\begin{tabular}{|c|c|c|c|c|c|}
\hline Variable & $\begin{array}{l}\text { Frequency } \\
(\mathrm{n}=155)\end{array}$ & $\begin{array}{l}\text { Percentage } \\
(\%=100)\end{array}$ & Mean & Minimum & Maximum \\
\hline Educational level of household heads & 0 & 0 & & & \\
\hline No formal education & 17 & 11 & & & \\
\hline Primary education & 62 & 40 & & & \\
\hline Secondary education & 64 & 41.3 & & & \\
\hline OND/ Diploma & 11 & 7.1 & & & \\
\hline $\mathrm{HND} / \mathrm{BSc}$ & 1 & 0.6 & & & \\
\hline \multicolumn{6}{|l|}{ Master } \\
\hline Household size (Number of person) & 19 & 12.3 & & & \\
\hline $1-3$ & 49 & 31.6 & & & \\
\hline 4-6 & 60 & 38.7 & 7 & 1 & 23 \\
\hline $7-9$ & 26 & 16.8 & & & \\
\hline $10-13$ & 1 & 0.6 & & & \\
\hline \multicolumn{6}{|l|}{$>13$} \\
\hline Farming Experience & 6 & 3.9 & & & \\
\hline $1-10$ & 28 & 18 & & & \\
\hline $11-20$ & 40 & 25.8 & 32 & 1 & 50 \\
\hline \multirow{2}{*}{\multicolumn{6}{|c|}{$>30$}} \\
\hline & & & & & \\
\hline Maize farm size (ha) & 20 & 19.4 & & & \\
\hline$<1$ & 77 & 49.6 & & & \\
\hline $1-2.4$ & 29 & 18.7 & 2.14 & 0.13 & 6 \\
\hline $2.5-3.9$ & 12.2 & 12.3 & & & \\
\hline \multicolumn{6}{|l|}{$\geq 4.0$} \\
\hline Other crop farm size (ha) & 99 & 64.2 & & & \\
\hline$<1<-<1<-<1$ & 33 & 21.5 & & & \\
\hline $1-2.4$ & 21 & 13.6 & 1.24 & 0.06 & 4.8 \\
\hline $2.5-3.9$ & 2 & 1.3 & & & \\
\hline \multicolumn{6}{|l|}{$\geq 4.0$} \\
\hline Member of social organization & 93 & 60 & & & \\
\hline Yes & 62 & 40 & & & \\
\hline \multicolumn{6}{|l|}{ No } \\
\hline Member of cooperative & 112 & 72.3 & & & \\
\hline Yes & 43 & 27.7 & & & \\
\hline \multicolumn{6}{|l|}{ No } \\
\hline Access to credit facilities & 93 & 60 & & & \\
\hline Yes & 62 & 40 & & & \\
\hline \multicolumn{6}{|l|}{ No } \\
\hline & 93 & 60 & & & \\
\hline \multirow{2}{*}{\multicolumn{6}{|c|}{ Yes }} \\
\hline & & & & & \\
\hline No & & & & & \\
\hline
\end{tabular}

Source: Field survey, 2019

\subsection{Dimensions of Food Security}

\subsubsection{Perception of the household heads on food availability}

Table 2 shows the perception of the household heads on food available to the households. Most (77.4\%) of the household heads said that food was moderately available for consumption throughout the year, $11.6 \%$ and $10.3 \%$ said that food was highly available and available respectively, while $0.6 \%$ claimed that food was scarcely available to the house throughout the year. The mean (4.00) shows that at an average the respondents perceived food to be moderately available in their households. This might be due to the fact that most people in the communities were into agriculture as it is a rural area and there were markets close to the people. Their perception of food availability should have a positive effect on food security as food availability is one of the dimensions of food security. 
Table 2: Perception of the household heads on food availability

\begin{tabular}{llll}
\hline Food availability & Frequency & Percentage & Mean \\
\hline Highly available & 18 & 11.6 & \\
Moderately available & 120 & 77.4 & \\
Available & 16 & 10.3 & 4.00 \\
Scarcely available & 1 & 0.6 & \\
Not available & 0 & 0 & \\
Total & 155 & 100 & \\
\hline
\end{tabular}

Source: Field survey, 2019

\subsubsection{Number of square meals consumed}

The number of square meals consumed per day is presented in Table 3. Most $(81.3 \%)$ of the farming households ate three square meals a day as food is very important to have strength for their daily activities, $18.1 \%$ of the households ate twice a day while $0.6 \%$ responded that they ate only once a day. This implies that the maize farming households took consumption of food important. Also, the availability of food in the study area (Table 2) had positive impact on their consumption as they had food available to eat.

Table 3: Number of square meals consumed per day

\begin{tabular}{lll}
\hline Numbers of meals & Frequency & Percentage \\
\hline 1 & 1 & 0.6 \\
2 & 28 & 18.1 \\
3 & 126 & 81.3 \\
Total & 155 & 100 \\
\hline
\end{tabular}

Source: Field survey, 2019

3.2.3 Perceived level of food quality consumed

Table 4 shows the perceived level of food quality consumed by the farmers throughout the year. Most (81.2\%) of the respondents perceived their food quality consumed to be high, $13.5 \%$ responded very high while just $5.2 \%$ responded that the food quality consumed by the households was low. This might be due to the fact that most of the farming households had some foods and fruits grown around them and they could get them fresh most of the time and most food stuff was readily available to them. This reflects two elements of food security, which are accessibility and utilization. This is because level of food quality is determined by access to the food and its utilization. Besides, the level of food quality consumed was high throughout the year which indicates sustainability of food access, one of the dimensions of food security.

Table 4: Perceived level of food quality consumed throughout the year

\begin{tabular}{llll}
\hline Food quality & Frequency & Percentage & mean \\
\hline Very high & 21 & 13.5 & 3.10 \\
High & 126 & 81.2 & \\
Low & 8 & 5.2 & \\
Very low & 0 & 0 & \\
Total & 155 & 100 & \\
\hline
\end{tabular}

Source: Field survey, 2019

\subsection{Food Security Status of Maize Farming Households}

The result of food security status of the maize farming households presented in Table 5 showed that $97 \%$ of the households were food secured while only $3 \%$ households were food in-secured, indicating that in the study area, most maize farming households were food secured. This is contrary to the high level of food insecurity reported in Nigeria (Ahmadu and Okoror, 2019; Ahmadu and Okoror, 2021). Majority of the households were food secured because they met the required dimensions of food security: they had food available to them (Table 2), ate three times a day (Table 3) and had sustained access to food of high quality (Table 4).

Table 5: Estimated food security status of maize farming households

\begin{tabular}{lll}
\hline Food security status & Frequency & Percentage \\
\hline Food Secure & 150 & 97.0 \\
Food insecure & 5 & 3.0 \\
Total & 155 & 100.0 \\
\hline
\end{tabular}

Source: Field survey, 2019

Recommended per capita calorie intake: $2730 \mathrm{k} / \mathrm{cal}$ (FAO, 1996)

3.4 Determinants of Food Security among Maize Farming Households

The results of the determinants of food security among maize farming households in the study area are presented in Table 6. Significant determinants of the maize farming households' food security status were farm size, 
household size and access to credit facilities.

Farm size of the households was significant at less than 5\% probability level and showed a positive relationship in explaining the status of household food security. This result explains that farming households with larger farm size are likely to be food secure than those with smaller farm size. The result showed that the odds ratio in favour of food security increased by the factor of 10.223 when the area of land under cultivation increased by one hectare. This implies that the more the farmers increased the hectares of farm land used for farming, the more food secured they were. This finding disagrees with the research conducted by Onasanya and Obayelu (2015) in Oyo State who obtained a negative and significant relationship of farm size to food security status. However, it agrees with the findings of Muche et al. (2014) in Ethiopia and Osei et al. (2013) in Ghana which indicated that the size of a land owned by farming households had a positive relationship with an improvement in household food security status.

Household size is the total number of people living together under the same roof and eating in the same pot in that house. This was significant at $10 \%$ probability level and had a negative influence on the status of household food security. This means that households with lesser household size were better food secured compared to those with larger household size. The odd ratio in favour of food security increased by a factor of 0.367 when the household size decreased by one person. An increase in the size of household implies more mouths to feed which leads to low average food, per capita expenditure and per household food consumption. This result is consistent with the finding of Djangmah (2016) in Ghana.

Access to Credit facilities was significant at less than 5\% probability level and had a positive influence on the status of household food security. This means that households that had access to credit facilities were more food secured. This indicates that these households had access to more capital to expand their farming which inturn affected production, income and directly affected food security.

Other variables such as total income per annum, years of experience of farmers, educational level of household head, age of household head and access to extension services were not significant factors affecting food security of maize farming households in the study area.

Table 6: Logit regression estimates of factors influencing food security status of maize farming households

\begin{tabular}{lllll}
\hline Variables & Coefficient & $\mathbf{Z}$-values & $\mathbf{P}>|\mathbf{z}|$ & Odds Ratio \\
\hline Total income per annum & $1.01 \mathrm{e}^{-06}$ & 0.5600 & 0.5780 & 1.0000 \\
Years of experience & 0.07304 & 0.9000 & 03680 & 1.0758 \\
Total farm size & $2.3246^{* *}$ & 2.1400 & 0.0320 & 10.2226 \\
Education & -0.5299 & -1.2100 & 0.2250 & 0.5885 \\
Age of household head & -0.1050 & -0.8000 & 0.4260 & 0.9003 \\
Household size & $-1.0001^{*}$ & -1.6900 & 0.0920 & 0.3674 \\
Access to extension service & -4.9742 & -1.4700 & 0.1420 & 0.0069 \\
Access to credit facilities & $4.3821^{* *}$ & 2.3800 & 0.0170 & 80.1597 \\
constant & 17.5098 & 1.3100 & 0.1900 & $4.06 \mathrm{e}^{+07}$ \\
\hline
\end{tabular}

Number of observations $=155$

Likelihood Ratio $\mathrm{chi}^{2}=24.7400$

Probability $>$ chi $^{2}=0.0017$

Pseudo $\mathrm{R}^{2} \quad=0.5599$

Log likelihood $\quad=-9.7202$

Source: Field survey 2019

*** Significant at less than $1 \%$ probability level; ** Significant at less than $5 \%$ probability level; * Significant at less than $10 \%$ probability level.

\section{Conclusion}

The study found that majority of the maize farming households in the study area met the required dimensions of food security: they had food available to them, ate three times a day and had sustained access to food of high quality. Consequently, they were food secure. Significant determinants of food security status among the households were farm size, household size and access to credit facilities. Farm size and access to credit facilities influenced food security positively while household size affected it negatively.

\section{Recommendations}

Based on the findings of this study, the following recommendations are made:

1. Government should create enabling environment for the farmers to access more arable land to help them expand their production in order to improve food security for both the farmers and the citizens at large.

2. Credit Facilities should be made more available and less stressful to access through making the process transparent and enlightenment of how to access credit. More organization should show interest on funding agriculture in the state as this will translate to improve the food security of the state at large. 


\section{References}

Ahmadu J., Okoror, O.T. (2019). Analysis of Food Security Status of Farmers in Ovia North-East Local Government Area, Edo State, Nigeria. Agricultural and Food Science Journal of Ghana 12: 1133 -1145. Available online at: https://www.ajol.info/index.php/afsjg/article/view/193116.

Ahmadu, J. and Okoror, O.T. (2021). Effect of Socio-Economic Characteristics on Food Security Status of Catfish Farmers in Edo South, Edo State, Nigeria. Advance Journal of Agriculture and Ecology 5 (2): $1-13$. Available online at: ajae_210305883.

Ajah, J. and Nmadu, J. (2012). Small-scale maize farmers access to farm inputs in Abuja, Nigeria. Kasetsart Journal - Social Sciences. 33. 499-505.Djangmah, G. M. (2016). Comparative Analysis of Food Security Status of Farming Households in Eastern and Northern Regions of Ghana. Department of Agricultural Economics, McGill University, Montreal; Quebec, Canada.

Djangmah, G. M. (2016). Comparative Analysis of Food Security Status of Farming Households in Eastern and Northern Regions of Ghana. Department of Agricultural Economics, McGill University, Montreal; Quebec, Canada.

Edeoghon, C.O. and Idowu A.A, (2017). Role of Agricultural enterprises in food security status of of urban farmers in Ikorodu metropolis, Lagos State, Nigeria. Ethopian Journal of Environment studies and management, 10(3). pp 404-414

Ehebhamen, O. G., Obayelu, A.E., Vaughan, I.O. and Afolabi,W.A.O., (2017). Rural households' food security status and coping strategies in Edo State Nigeria. International Food Research Journal 24(1): 333-340.

FAO, (2010). Nutrition Security and Food Security in Seven Districts in NTT Province, Indonesia: Status, Causes and Recommendations for Response. Final Report, Jakarta and Rome.

FAO/ IFAD/WFP. (2015). The State of Food Insecurity in the World 2015. Meeting the 2015 International Hunger Targets: Taking Stock Of Uneven Progress FAO, Rome.

FAO/IFAD/WFP. (2015). The State of Food Insecurity in the World 2015. Meeting the 2015 International Hunger Targets: Taking Stock Of Uneven Progress FAO, Rome.

IFAD (2001). The rural poverty report, International Fund for Agricultural Development: Rome, Italy. Retrieved from http.//www.ifad.org/poverty/index.htm (Accessed on 4th May, 2009).

Jrad, S., Nahas, B., and Baghasa, H. (2010). Food Security Models. Ministry of Agriculture and Agrarian Reform, National Agricultural Policy Centre. Policy Brief No 33. Pp 3. Syrian Arabic Republic.

Krejcie, R.V. and Morgan, D.W. (1970). Determining sample size for research activities. Educational and Psychological Measurement, 30(3): 607-610.

Millennium Institute (2013). Global Food and Nutrition Scenarios Final Report. Millennium Institute, Washington, $\mathrm{DC}$, March 15 th. https://www.un.org/en/development/desa/policy/wess/wess_bg_papers/bp_wess2013_millennium_inst.pdf

Muche, M., Endalew B., and T. Koricho. (2014). Determinants of household food security among Southwest Ethiopia rural households. Asian Journal of Agricultural Research, 1819-1894, DOI: 10.3923/ajar.

OECD (2008), Growing Unequal ? Income Distribution and Poverty in OECD Countries, Paris.

OECD (2011), Divided We Stand - Why Inequality Keeps Rising, Paris. (www.oecd.org/social/inequality.htm / www.oecd.org/fr/social/inegalite.htm )

Ogunlade I., Olaoye G., Tologbonse D. and Alaoye O. E. A. (2010). On-farm Evaluation of Drought Tolerant Maize Varieties and Hybrids in the Southern Guinea Savanna Zones of Nigeria. Proceedings of the 44th Annual Conference of the South African Society for Agricultural Extension, May 4-7, 2010, Langebaan, Western Cape, South Africa, pp: 1-5.

Olaniyi O. A and Adewale J. G. 2012. Information on Maize Production among Rural Youth: A Solution for Sustainable Food Security in Nigeria. Library Philosophy and Practice 2012. http://digitalcommons.unl.edu/cgi/viewcontent.cgi?article=1798andcontext=libphilprac

Onasanya, O. A., and Obayelu, O. A. (2016). Determinants of Food Security Status of Maize-Based Farming Households in Southern Guinea Savannah Area of Oyo State, Nigeria: Turkish Journal of Agriculture - Food Science and Technology, 4(5): 411-417.

Osei, M.J., Aidoo, R. and Tuffour, T. (2013). Determinants of Household Food Security in the Sekyere-Afram Plains District of Ghana. Global Advanced Research Journal of Agricultural Science, 2(034-040), 2315-5094. http://garj.org/garjas/index.htm

Rosegrant M.W., Msangi S., Ringler C., Sulser T.B., Zhu T. and Cline S.A. (2008). International Model for Policy Analysis of Agricultural Commodities and Trade (IMPACT): Model Description. International Food Policy Research Institute, Washington, D.C.

Smith, C .L. \&Subandoro, A. (2007). Measuring food security using household expenditure surveys, Washington DC, USA: International Food Policy Research Institute.

Szumilas, M. (2010). Explaining Odds Ratios. Journal of the Canadian Academy of Child and Adolesce nt Psychiatry 19(3), 227. 